\title{
PENGARUH PEMBERIAN LAYANAN BIMBINGAN KELOMPOK \\ TERHADAP KEMANDIRIAN SISWA YANG TIDAK AKTIF MENGIKUTI KEGIATAN EKSTRAKURIKULER PRAMUKA PADA SISWA KELAS VII-4 DI SMP NEGERI 2 BANDAR KHALIPAH
}

\author{
Riza Hariati Br Siregar', Dra. Zuraida Lubis, M.Pd.Kons ${ }^{2}$ \\ Program Studi Bimbingan dan Konseling, FIP - Universitas Negeri Medan
}

\begin{abstract}
Abstrak
Penelitian ini bertujuan untuk mengetahui tingkat kemandirian siswa yang tidak aktif mengikuti ekstrakurikuler pramuka di Kelas VII-4 SMP Negeri 2 Bandar Khalipah. Metode penelitian ini adalah kuantitatif dengan eksperimen semu, dengan desain pre test-post test one group design. Populasi dalam penelitian ini adalah seluruh siswa kelas VII-4. Sampel ditarik dengan menggunakan metode purposive sampling sebanyak 10 orang yang berasal dari kelas VII-4 dengan sampel yang homogen. Data penelitian ini dikumpulkan dengan menggunakan angket kemandirian siswa berjumlah 37 item pernyataan yang telah valid dan reliabel kemudian data dianalisis menggunakan uji Wilcoxon. Dari analisis data diperoleh $\mathrm{J}$ hitung $=21$ dengan $\alpha=0,05$, adapun $\mathrm{J}$ tabel $=8$. Dari data tersebut terlihat bahwa $\mathbf{J}_{\text {hitung }}>\mathbf{J}_{\text {Tabel }}$ dimana $17>4$. Artinya hipotesis diterima. Data pretest kemandirian siswa yang tidak aktif mengikuti kegiatan ekstrakurikuler diperoleh skor rata-rata 72,5 sedangkan data post-test kemandirian siswa yang tidak aktif mengikuti kegiatan ekstrakurikuler diperoleh skor rata-rata sebesar 83,6 . Artinya skor rata-rata siswa setelah mendapat bimbingan kelompok lebih tinggi dari pada sebelum mendapat bimbingan kelompok kemandirian siswa yang tidak aktif mengikuti kegiatan ekstrakurikuler di kelas VII-4 SMP Negeri 2 Bandar Khalipah.
\end{abstract}

Kata Kunci : Layanan Bimbingan kelompok, Kemandirian.

PENDAHULUAN

Dalam pembukaan UUD bakatnya sendiri terlepas dari status 1945, dinyatakan bahwa salah satu sosial, ras, etnis, agama dan gender. tujuan Nasional Negara Indonesia Hal ini sesuai dengan tujuan adalah mencerdaskan kehidupan pendidikan nasional yang tercantum bangsa.Karena alasan itu, setiap dalam pasal 3 ayat 1 Undang-undang warga negara memiliki hak untuk Nomor 20 tahun 2003 tentang Sistem memiliki kualitas hidup menurut

Pendidikan Nasional yaitu: 
pendidikan nasional berfungsi mengembangkan kemampuan dan membentuk watak serta peradaban bangsa yang bermartabat dalam rangka mencerdaskan kehidupan bangsa, bertujuan untuk berkembangnya potensi peserta didik agar menjadi manusia yang beriman dan bertaqwa kepada Tuhan Yang Maha Esa, berakhlak mulia, sehat, berilmu, cakap, kreatif, mandiri, dan menjadi warga negara yang demokratis serta bertanggung jawab (UUSPN, 2003).

\section{Pendidikan} mampu menciptakan sumber daya manusia yang berkualitas, memiliki pandangan luas dan maju untuk mencapai cita-cita yang diinginkan. Pendidikan disekolah sendiri dilaksanakan di dalam kelas maupun diluar kelas, kegiatan yang ada di luar kelas berupa kegiatan yang dapatmengembangkan kepribadian siswa yang nantinya sebagai bekal kemampuan dasar siswa untuk terjun ke masyarakat. Salah satu pendidikan yang dapat membentuk kepribadian siswa adalah melalui kegiatan ekstrakurikuler yang ada di sekolah.

Sekolah adalah suatu lembaga yang memang dirancang khusus untuk pengajaran para murid (siswa) di bawah pengawasan para guru. Sekolah yang pada dasarnya sebagai sarana untuk melaksanakan pendidikan memang diharapkan bisa menjadikan masyarakat yang lebih maju, oleh sebab itu sekolah sebagai pusat pendidikan harus bisa melaksanakan fungsinya dengan optimal dan perannya bisa menyiapkan para generasi muda sebelum mereka terjun di dalam proses pembangunan masyarakat. Lebih lanjut dijelaskan dalam Undang-undang Nomor 20 Tahun 2003 yang membahas Tentang sistem Pendidikan Nasional, pendidikan diartikan sebagai usaha sadar dan terencana untuk mewujudkan suasana belajar dan proses pembelajaran agar peserta didik secara aktif mengembangkan potensi dirinya untuk memiliki kekuatan spiritual keagamaan, pengendalian diri, kepribadian, kecerdasan akhlak mulia, serta keterampilan yang diperlukan dirinya, masyarakat, bangsa dan negara. Setiap sekolah dalam rangka meningkatkan kualitas pendidikan, dan mencetak generasi pemimpin penerus bangsa, perlu melakukan upaya-upaya untuk 
meningkatkan sikap kepemimpinan pada diri peserta didik seperti menumbuhkan kepercayaan diri siswa untuk menjadi seorang pemimpin, membuat siswa untuk dapat menjadi pemimpin dan bertanggung jawab pada dirinya sendiri, serta membuat siswa berani menunjukkan kemampuannya.

Dalam pelaksanaan aktivitas siswa di sekolah tidak hanya belajar formal saja akan tetapi ada satu kegiatan yaitu kegiatan ekstrakurikuler. Kegiatan ini merupakan kegiatan yang diselenggarakan di luar jam pelajaran yang tercantum dalam program dengan keadaan dan kebutuhan sekolah untuk membantu mengembankan siswa sesuai kebutuhan, terutama potensi mereka, bakat dan minat melalui kegiatan yang dirancang khusus oleh instruktur atau staf pendidik yang memiliki kemampuan otoritas di sekolah.

$\begin{array}{lcr} & \text { Ekstrakurikuler } & \text { pramuka } \\ \text { saat ini dimasukkan } & \text { dalam } \\ \text { kurikulum } & 2013 \text { sebagai } \\ \text { ekstrakulikuler } & \text { wajib,namun pada } \\ \text { hakikatnya pramuka dikelola oleh } \\ \text { Gerakan Pramuka seperti yang }\end{array}$

tertuang dalam Pasal 5 Keppres no 24 Tahun 2009 yang berbunyi: Gerakan pramuka mempunyai tugas pokok menyelenggarakan ekstrakurikuler pramuka bagi kaum guna menumbuhkan tunas bangsa agarmen jadi generasi yang lebih baik, bertanggung jawab, mampu membina dan mengisi kemerdekaan nasional serta membangun dunia yang lebih baik. Dijelaskan dalam pasal berikutnya yang menjelaskan bahwa Gerakan Pramuka dapat berfungsi sebagai organisasi pendidikan non formal, sebagai wadah pembinaan dan pengemban gangenerasi muda adapun pelaksanaannya disesuaikan dengan keadaan, kepetingan, dan perkembangan bangsa serta masyarakat Indonesia.

Menurut Thomas Lickona 2012: 469 Kegiatan ekstrakurikuler adalah kegiatan untuk mengefektifkan siswa dalam kegiatan sekolah dan dapat membantu siswa membangun tingkat kemandirian sebagai anggota komunitas sekolah. Kegiatan ekstrakurikuler yang dilaksanakan di luar jam pelajaran sekolah sudah tercantum dalam susunan program 
sesuai dengan keadaan dan kebutuhan sekolah. Kegiatan ekstrakurikuler merupakan kegiatan pengayaan dan kegiatan perbaikan yang berhubungan dengan program kurikuler. Kegiatan ekstrakurikuler lebih diarahkan untuk pembentukan kepribadian anak melalui kegiatan seperti Pramuka, UKS, Olahraga, Keseniandan Palang Merah Remaja. Salah satu kegiatan ekstrakurikuler yang mampu membentuk karakter siswa melalui kegiatan pramuka.

Salah satunya adalah ekstrakurikuler pramuka Mulyono (dalam Kompri, 2015) menjelaskan bahwa "kata ekstrakurikuler memiliki arti kegiatan tambahan di luar rencana pelajaran atau pendidikan tambahan di luar kurikulum". Dengan demikian, kegiatan ekstrakurikuler merupakan kegiatan yang dilakukan di luar kelas dan diluar jam pelajaran untuk menumbuh kembangkan potensi sumber daya manusia yang dimiliki peserta didik, baik yang berkaitan dengan aplikasi ilmu pengetahuan yang didapatkannya maupun dalam pengertian khusus untuk membimbing peserta didik dalam mengembangkan potensi dan bakat yang ada dalam dirinya melalui melalui kegiatan-kegiatan yang wajib maupun pilihan. Kegiatan ekstrakurikuler pramuka bersifat menyenangkan dan membangun karakter siswa karena kegiatan ini berada di luar kelas sehingga siswa akan lebih mudah memahami materi yang ada di pramuka secara lebih cepat karena siswa dapat memperoleh pembelajaran secara nyata, dalam kegiatan pramuka dapat membentuk sikap kemandirian, kedisiplinan, dan sebagainya. Dengan adanya kegiatan ekstrakurikuler pramuka di sekolah diharapkan tidak menggangu prestasi belajar siswa dikelas.

Namun pada kenyataannya dari hasil wawancara saya dengan guru BK, ada $75 \%$ siswa kelas VII di sekolah SMP N 2 Bandar Khalipah yang masih rendah tingkat kemandiriannya. Hal ini dapat dilihat dari permasalahan yang nampak pada kelas VII-4 diantaranya adalah $38 \%$ siswa tidak yakin pada kemampuan diri sendiri, $23 \%$ siswa minta diarahkan oleh guru dalam belajar secara terus menerus, $43 \%$ tidak mampu belajar mandiri, $60 \%$ siswa membutuhkan dukungan orang lain 
dalam menyelesaikan masalahnya sendiri, $75 \%$ siswa menggunakan waktu belajar di sekolah untuk bermain pada saat jam kosong, 50\% siswa sering menyontek pekerjaan teman saat ada tugas maupun saat ulangan berlangsung, apabila ada pekerjaan rumah sering tidak mengerjakan, $49 \%$ siswa tidak memiliki tanggung jawab dalam melaksanakan tugas, $27 \%$ siswa melaksanakan kegiatan harus berdasarkan perintah orang lain, $41 \%$ siswa selalu ingin cepat-cepat mengakhiri kegiatan belajarnya. Fenomena di atas mengambarkan bahwa rendahnya tingkat kemandirian siswa yang tidak mengikuti kegiatan ekstrakurikuler. Apabila keadaan yang seperti ini tidak ditangani, dikhawatirkan akan berbengaruh terhadap prestasi belajar siswa di sekolah.

Bimbingan kelompok adalah salah satu bentuk layanan bimbingan yang diberikan kepada siswa secara bersama-sama atau kelompok dalam memperoleh berbagai bahan dari pembimbing yang berguna untuk menunjang kehidupannya seharihari.Dalam bimbingan kelompok ada beberapa teknik yang dapat digunakan, yaitu program home rome, karyawisata, diskusi kelompok, kegiatan kelompok, organisasi siswa, sosiodrama, psikodrama, dan pengajaran remedial. Sehingga memungkinkan pikiran, perasaan, dan harapan semua peserta dapat saling menghargai karakter masing-masing.

Bimbingan dan konseling merupakan salah satu komponen sekolah, pelaksanaan bimbingan dan konseling tidak lepas dari fungsi dan tujuan pendidikan. Pelaksanaan bimbingan dan konseling disekolah dilakukan oleh konselor sekolah atau guru BK sebagaimana telah di akui oleh Undang-Undang Sistem Pendidkan Nasional Tahun 2003 pasal 1. Melalui layanan bimbingan dan konseling yang dilakukan konselor dapat membantu siswa mencapai individu yang memiliki tingkat kemandirian tinggi. Layanan dan konseling di sekolah meliputi layanan oreantasi, informasi, penguasaan konten, penempatan penyaluran, bimbingan kelompok, konseling kelompok, konsultasi, layanan mediasi. Dalam memberikan layanan ada yang bersifat secara pribadi, klasikal, bersifat kelompok. 
Kondisi tingkat kemandirian siswa yang ada di sekolah pada umumnya bervariasi, ada siswa yang memiliki tingkat kemandirian rendah, sedang, tinggi, sangat tinggi. Layanan bimbingan kelompok dapat di asumsikan sebagai layanan yang tepat dalam membantu meningkatkan kemandirian siswa. Bimbingan kelompok merupakan sebagai media dalam upaya membimbimbing siswa yang bertujuan untuk mengembangkan perasaan berfikir, persepsi, wawasan dan sikap terarah kepada tingkah laku yang diinginkan dengan memanfaatkan dinamika kelompok. Melalui bimbingan kelompok siswa mendapat berbagai informasi tentang sikap mandiri dan melalui dinamika kelompok siswa dapat belajar berinteraksi dengan anggota kelompok yang mempunyai pengetahuan, pengalaman, gagasan tentang sikap mandiri yang berbedabeda. Berkembangnya wawasan, perasaan, berfikir, berpersepsi dari siswa dalam kegiatan layanan bimbingan kelompok akan mendorong siswa untuk dapat menyelesaikan masalahnya, mampu mengarahkan dirinya, memiliki pandangan hidup sendiri, mampu mengatur kehidupannya sendiri, serta berani menanggung segala akibat dari tindakan yang dilakukannya, dengan kata lain siswa dapat mengemban kemandirian serta mungkin sekali kemandirian siswa meningkat.

\section{KAJIAN PUSTAKA}

Kemandirian adalah melakukan segala sesuatu dengan kemampuan dan usaha sendiri. Tetapi kenyataannya pada saat ini adalah kurangnya sikap kemandiran siswa menyebabkan banyak siswa yang tidak bisa melakukan tugas nya sendiri meskipun pada hakikat nya manusia itu tidak lepas dari yang namanya bantuan orang lain. Contoh nya di SMP N 2 Bandar khalipah kurangnya rasa tanggung jawab siswa terhadap tugas yang diberikan oleh para guru, kurangnya rasa percaya diri, kurang berinisiatif, dan tidak dapat mengatasi masalah/ hambatan sendiri.

Untuk mengatasi hal ini salah satu cara yang dapat dilakukan yaitu bimbingan kelompok. Melalui bimbingan kelompok memungkinkan sejumlah siswa bersama-sama melalui dinamika kelompok memperoleh bahan dan bahasan 
topik mengenai pemahaman dan pengembangan siswa terhadap sikap kemandirian, serta mendapatkan informasi mengenaicara meningkatkan sikap kemandirian, serta penunjang pengembangan kemampuan sosial siswa melalui dinamika kelompok.

Melalui layanan bimbingan kelompok ini, diharapkan akan memperoleh solusi yang tepat untuk menyelesaikan masalah yang dialami oleh para siswa, sehingga siswa mampu meningkatkan sikap kemandirian siswa.

\section{METODE PENELITIAN}

Adapun jenis dari penelitian ini adalah penelitian eksperimen semu, yaitu penelitian yang memberikan perlakuan kepada sekelompok orang yang dijadikan subjek penelitian.

Subjek penelitian adalah siswa kelas VII-4 yang tidak aktif mengikuti kegiatan ekstrakurikuler Pramuka di SMP N 2 Bandar khalipah.

Dalam Penelitian ini peneliti hanya meneliti 10 orang siswa dari kelas VII-4 di SMP Negeri 2 Bandar Khalipah sebagai subjek penelitian berdasarkan tingkat terendah dari perhitungan angket kemandirian dan juga berdasarkan wawancara dengan guru pembimbing dan catatan yang ada di sekolah. Menurut Prayitno (2004 : 314) mengatakan bahwa "standar pelaksanaan bimbingan kelompok yang efektif dalam satu kelompok adalah berjumlah 5-10 siswa.

Terdapat dua variabel dalam penelitian ini,yaitu variabel bebas (X) dan variabel terikat (Y) :

Variabel Bebas $(\mathrm{X}) \quad$ : $\quad$ Bimbingan Kelompok

Variabel Terikat (Y) : Kemandirian

Desain yang digunakan dalam penelitian ini adalah menggunakan desain one group pre-test dan posttest design.

\section{HASIL PENELITIAN DAN PEMBAHASAN \\ Menurunnya sikap} kemandirian siswa SMP Negeri 2 Bandar Khalipah. Subjek penelitian ini adalah siswa kelas VII-4 sebanyak 10 orang.Hasil penelitian yang dilakukan di SMP Negeri 2 Bandar Khalipah kelas VIImenunjukkan adanya pengaruh pemberian layanan bimbingan kelompok kemandirian siswa.Hal tersebut dapat dilihat dari meningkatnya nilai post-test setelah 
$\begin{array}{lrr}\text { diberikan } & \text { layanan } & \text { bimbingan } \\ \text { kelompok } & \text { terhadap } & \text { kemandirian } \\ \text { siswa. } & & \end{array}$ Sebelum dilaksanakan layanan bimbingan kelompok terhadap 10 siswa yang memiliki kemandirian tergolong rendah, didapatkan jumlah persentase siswa yang sikap kemandiriannya rendah sebesar $60 \%$, siswa yang memiliki kemandirian sedang sebesar 20\%, dan siswa yang memiliki kemandiriantinggi sebesar $20 \%$. Siswa dengan kategori kemandirian rendah adalah 6 orang, siswa dengan kategori memiliki kemandirian yang sedang adalah RC dan AD, siswa dengan memiliki kemandirian yang tinggi adalah SU, KA.

Pelaksanaan penelitian ini sebanyak 6 kali pertemuan. Pada pertemuan pertama, peneliti melaksanakan bimbingan topik Bertanggung jawab, pertemuan kedua dengan topik pembahasan bekerja keras dan bersungguhsungguh, pertemuan ketiga dengan topic pembahasan Berani bertindak atau berinisiatif, pertemuan yang keempat dengan topik pembahasan. Bekerja sama dan bersahabat, pertemuan yang kelima dengan topik pembahasan Bersosialisasi dan pertemuan keenam dengan topik pembahasan Ulet dan tekun. Topik ini diambil sesuai dengan permasalahan yang terjadi.

Setelah dilaksanakan layanan bimbingan kelompok terhadap 10 siswa yang memiliki kemandirian yang tergolong tinggi, didapatkan jumlah persentase siswa yang memiliki kemandirian rendah sebesar 0\% (tidak ada), siswa yang memiliki kemandirian sedang sebesar 30\%, dan siswa yang memiliki kemandiran tinggi sebesar $70 \%$. Siswa dengan kateogori memiliki kemandirian yang tinggi adalah $\mathrm{GF}, \mathrm{AD}, \mathrm{SS}, \mathrm{SU}$, KA (ganti) dan $\mathrm{MH}$ siswa dengan kategori memiliki kemandirian yang sedang adalah R (ganti ) C dan HD, setelah dilakukan layanan bimbingan kelompok.

Hasil penelitian ini menunjukkan adanya peningkatan kemandirian siswa kelas VII-4 SMP Negeri 2 Bandar Khalipah setelah diberikan layanan bimbingan kelompok.

Berdasarkan hasil uji hipotesis dikemukakan bahwa bimbingan kelompok dapat meningkatkan sikap kemandirian 
siswa. Hal ini ditandai dengan adanya perbedaan yang signifikan sebelum dan sesudah dilakukan bimbingan kelompok.

\section{PENUTUP}

\section{Kesimpulan}

Berdasarkan hasil penelitian yang telah dilaksanakan oleh peneliti, maka diperoleh kesimpulan bahwa ada pengaruh layanan bimbingan kelompok terhadap kemandirian siwa yang tidak aktif mengikuti kegiatan ekstrakurikuler Pramuka dikelas SMP N 2 Bandar Khalipah

Setelah melaksanakan kegiatan bimbingan kelompok siswa lebih meningkatkan sikap kemandirian nya dalam kelas dan aktivitas seharihari. Para siswa menjadi lebih mandiri dalam mengerjakan tugastugasnya lebih disiplin disekolah.

Hasil analisa data yang diperoleh dalam penelitian ini adalah nilai hitung $=17$ dengan $\alpha=0,05$ dan $\mathrm{n}=10$. Maka berdasarkan daftar , $\mathbf{J}$ tabel $=8$. Dari data tersebut terlihat bahwa $\mathrm{J}_{\text {hitung }}>\mathrm{J}_{\text {Tabel }}$ dimana 17> 8.Artinya hipotesis diterima. Data pre-test diperoleh rata-rata 72,5, sedangkan data post-test setelah diberikan layanan bimbingan kelompok diproleh rata-rata sebesar 83,6. Artinya skor rata-rata siswa setelah mendapat layanan bimbingan kelompok lebih tinggi daripada sebelum mendapat layanan bimbingan kelompok.Hal ini menunjukkan bahwa hipotesis dapat diterima.

\section{Saran}

Adapun saran yang dapat dikemukakan peneliti adalah:

1. Diharapkan kepada Kepala Sekolah lebih memberikan fasilitas, sarana dan prasarana kegiatan layanan bimbingan dan konseling di sekolah agar tujuan yang diharapkan dapat tercapai secara optimal.

2. Guru pembimbing diharapkan menindaklanjuti kegiatan layanan bimbingan kelompok dengan mengadakan kegiatan bimbingan kelompok untuk penyelesaian yang lebih lanjut, terutama kepada siswa dengan inisial HP yang membutuhkan bimbingan dan arahan lebih dibandingkan dengan teman teman lainnya.

3. Bagi siswa/i yang masih memiliki tingkat kemandirian rendah bisa meminta bantuan kepada guru BK agar 
mengadakan kegiatan layanan

bimbingan konseling dan

mengikuti kegiatan yang

diadakan guru pembimbingnya.

4. Diharapkan bagi peneliti lain dapat dijadikan sebagai bahan masukan dan sumber referensi dalam penelitian di bidang yang sama terutama untuk menumbuh kembangkan kemampuan kemandirian.

5. Bagi siswa/i yang masih memiliki tingkat kemandirian rendah bisa meminta bantuan kepada guru BK agar mengadakan kegiatan layanan bimbingan konseling dan mengikuti kegiatan yang diadakan guru pembimbingnya.

6. Diharapkan bagi peneliti lain dapat dijadikan sebagai bahan masukan dan sumber referensi dalam penelitian di bidang yang sama terutama untuk menumbuh kembangkan kemampuan kemandirian.

\section{DAFTAR PUSTAKA}

Ahmad. 2006. Kamus Lengkap Bahasa Indonesia. Yogyakarta: Reality Publiser.

AzrulAzwar. 2009. Gerakan Pramuka: Anggaran Dasar dan Anggaran Rumah Tangga. Jakarta: Tunas Media.

Budi, T.P. 2006. Strategi hidup dan belajar mahasiswa indekos. Yogyakarta: Tugu Publisher

Hartinah, Sitti. 2009. Konsep Dasar Bimbingan Kelompok. Bandung: Refika Aditama

Istarani. 2015. Ensiklopedia Pendidikan. Medan: Larispa

Kompri. 2015. Manajemen Pendidikan. Yogyakarta : ArRuzz Media

Mutiara, Juliani. 2014. Perbedaan Prestasi Belajar Antara Siswa Yang Mengikuti Kegiatan Ekstrakurikuler Dengan Siswa Yang Tidak Mengikuti Kegiatan Ekstrakurikuler Pada Siswa Kelas XI SMA NEGERI 2 MEDAN.Skripsi

Menanti, Asih. 2013. Penelitian Eksperimen. Medan: Universitas Negeri Medan

Priyatna, Andri. 2012. Lets End Bullying: Flex Media Komputindo

Prayitno. 2012. Jenis Layanan Dan Kegiatan Pendukung Konseling. Padang: Universitas Negeri Padang

1995. Layanan Bimbingan Dan Konseling (Dasar dan Profil). Jakarta: Ghalia Indonesia 
Prayitno \&Amti , 2004. Dasar-Dasar Bimbingan Dan

Konseling.Jakarta : Rineka Cipta

Safitri, Dwi Nunik. 2013. Penanaman Karakter Kepemimpinan Melalui Kegiatan PRAMUKA Studi Kasus Kegiatan Ekstrakurikuler Pramuka Di SMP Al-Islam 1 Surakarta Tahun Pelajaran 2012/2013. Skripsi

Suwidang, Ahmad. 2011. Hubungan Pelaksanaan Bimbingan Konseling Dan Fasilitas Belajar Di Rumah Terhadap Motivasi Berprestasi Siswa Kelas X Jurusan Teknik Kendaraan Ringan SMK PIRI 1 Yogyakarta.Skripsi

Yamin, Ahmad. 2014. Pengaruh Layanan Pemberian Kelompok Dengan Tehnik Role Playing Terhadap Karakter Kemandirian Siswa Dalam Belajar Pada Kelas VIII SMP Negeri 3 Penanggalan T.A 2014/2015. Skripsi

Wiyani, N.A. 2013. Membumikan pendidikan karakter di SD. Jogjakarta: Ar-ruzz Media 